\title{
Deteksi dan Estimasi Kecepatan Kendaraan dalam Sistem Pengawasan Lalu Lintas Menggunakan Pengolahan Citra
}

Detection and Estimation of Vehicle Speed in Traffic Control Systems Using Image Processing

\author{
Muhammad Zulfikri ${ }^{1}$, Hairani $^{2}$, Ahmad $^{3}$, Kurniadin Abd. Latif $^{4}$, Rifqi Hammad ${ }^{5}$, Moch. Syahrir ${ }^{6}$ \\ ${ }_{1,2,3,4,5,6}$ Program Studi Sarjana Ilmu Komputer, Fakultas Teknik dan Desain, Universitas Bumigora \\ E-mail: ${ }^{1}$ mzulfikri@universitasbumigora.ac.id, ${ }^{2}$ hairani@universitasbumigora.ac.id, \\ ${ }^{3}$ ahmad@universitasbumigora.ac.id, ${ }^{4}$ kurniadin@universitasbumigora.ac.id, \\ 5rifqi.hammad@universitasbumigora.ac.id, ${ }^{5}$ muhammadsyahriralfath@gmail.com
}

\begin{abstract}
Abstrak
Deteksi objek berbasis pengolahan citra digital pada kendaraan sangat penting untuk diterapkan dalam membangun sistem pengawasan atau sebagai metode alternatif dalam mengumpulkan data statistik untuk pengambilan keputusan rekaya lalu lintas yang efisien. Pada penilitian ini, dibuat sistem deteksi kendaraan berbasis video lalu lintas untuk jenis kendaraan tertentu dengan menggunakan Haar Cascade Classifier dan estimasi kecepatan kendaraan dilakukan dengan menghitung perbedaan waktu pada Region of Interest (ROI) yang telah ditentukan dan hasilnya akan ditampilkan pada Radar Speed Design. Pengujian dilakukan dengan 5 video pengujian. Hasil yang didapatkan dari deteksi kendaraan yaitu nilai rata-rata recall 0.988 dan presisi 0.97 dan dari perhitungan kecepatan didapatkan nilai Mean Squared Error (MSE) yaitu 0,6.
\end{abstract}

Kata kunci: deteksi, kecepatan, kendaraan, haar cascade classifier, radar speed design.

\begin{abstract}
Object detection based on digital image processing on vehicles is very important to be applied in building a surveillance system or as an alternative method of collecting statistical data for efficient traffic engineering decision making. In this research, a traffic video-based vehicle detection system was created for certain types of vehicles using the Haar Cascade Classifier and the vehicle speed estimation was carried out by calculating the time difference in the determined Region of Interest (ROI) and the results will be displayed on the Radar Speed Design. Testing was carried out with 5 test videos. The results obtained from vehicle detection are the average recall value of 0.988 and precision of 0.97 and from the calculation of the speed, the Mean Squared Error (MSE) value is 0.6.
\end{abstract}

Keywords: detection, speed, vehicle, haar cascade classifier, radar speed design.

\section{PENDAHULUAN}

Sistem pengawasan lalu lintas yang efektif dan konsisten merupakan kebutuhan yang mendesak dalam memperluas kendali lalu lintas dan pengelolaannya. Arus lalu lintas dapat menunjukkan keadaan lalu lintas dalam interval waktu yang tetap dan membantu dalam mengatasi dan mengontrol terutama saat terjadi kemacetan lalu lintas dan ketika kecepatan kendaraan dapat menimbulkan terjadinya kecelakaan.

Di beberap ruas jalan, banyak ditemukan fasilitas rambu perintah lalu lintas yang berfungsi untuk menyatakan perintah yang wajib dilakukan setiap pengguna jalan demi terciptanya kelancaran dan kenyamanan saat berkendara. Rambu tersebut juga banyak di tempatkan di ruas jalan yang banyak di lalui oleh pejalan kaki, seperti daerah kampus (universitas). Karena banyak kampus yang mengizinkan akses kendaraan, dan interaksi pejalan kaki dengan kendaraan tidak dapat dihindari, yang dapat mengakibatkan terjadinya konflik dan potensi kecelakaan yang tinggi. Selain itu, gangguan dari telepon seluler bisa mengakibatkan banyak pejalan kaki dan pengemudi tidak sadar 
akan masalah tersebut. Beberapa faktor ini menunjukkan berbagai masalah dalam sistem transportasi di sekitar kampus. Perlunya pertimbangan yang matang untuk menerapkan desain teknik transportasi.

Berbagi cara dilakukan untuk menangani keselamatan bagi pejalan kaki. Diantaranya yaitu dengan mengurangi kecepatan kendaraan melalui sistem pengawasan dan penegakan lalu lintas. Pilihan pertama yang dapat dilakukan secara tradisional, menggunakan pistol radar. Dengan teknologi tersebut, kecepatan kendaraan dapat diketahui. Namun teknologi ini masih memiliki beberapa kelemahan seperti kesalahan kosinus yang terjadi ketika arah pistol radar tidak sesuai dengan kendaraan melintas. Selain itu, harga pistol radar yang mahal merupakan alasan penting, dan adanya interfensi radio (kesalahan yang disebabkan oleh adanya frekuensi gelombang radio yang sama) [1], [2]. Pilihan lainnya adalah dengan menerapkan sistem penegakan dalam bentuk polisi tidur yang dikombinasikan dengan teknik deteksi kecepatan kendaraan menggunakan sensor elektronik, yaitu dua buah sensor tekanan, yang dilakukan dengan menghitung perbedaan waktu pemicu antara sensor tersebut [3]. Namun sensor tersebut sensitif terhadap temperatur dan memerlukan perbaikan dan instalasi ulang jika diterapkan pada permukaan jalan kurang bagus [4]. Selain itu, pemasangan polisi tidur bisa menjadi permasalahan tersendiri, yaitu dapat memberikan ketidaknyamanan bagi pengemudi yang melaju dengan kecepatan rendah, dan perlunya polisi tidur yang aktif dinamis, berdasarkan estimasi kecepatan kendaraan yang melintas. Meskipun begitu, keberadaan polisi tidur tersebut masih memiliki sisi negatif terhadap keterlambatan kendaraan tanggap darurat seperti ambulan, atau truk pemadam kebakaran yang bisa menyebabkan kematian, cedera dan kehilangan harta benda. [5].

Dengan beberapa kelemahan tersebut, perlunya pengembangan dalam sistem deteksi kecepatan dan penegakan kendaraan. Perkembangan computer vision telah mengungkapkan bahwa penggunaan kamera video merupakan cara yang efisien dalam mengumpulkan dan menganalisis data lalu lintas, sehingga dapat digunakan dalam sistem deteksi kecepatan [6]. Sistem penegakan dapat diterapkan menggunakan sebuah indikator rambu kecepatan radar (radar speed signs), yaitu tanda interaktif pada umumnya ditampilkan dari serangkaian LED yang digunakan untuk menampilkan kecepatan kendaraan yang terdeteksi.

Penelitian sebelumnya menunjukkan bahwa penggunaan rambu tersebut sangat efektif dalam pengawasan lalu lintas. Selain itu, kebutuhan akan rambu lalu lintas sangat penting, karena dapat membantu pengemudi dalam mengurangi terjadinya kecelakaan fatal yang melibatkan pejalan kaki dan kendaraan. Rambu ini juga tidak memerlukan kehadiran polisi lalu lintas, sehingga dapat membantu menghemat uang dan waktu, dan memungkinkan polisi untuk fokus pada tugas langsung lainnya [7]-[9].

Untuk mendeteksi kendaraan, metode yang sering digunakan diantaranya adalah adaptive background subtraction yang digunakan untuk memisahkan antara latar belakang dengan objek yang di deteksi atau latar depan. Adaptive background subtraction umumnya digunakan untuk mendeteksi objek bergerak pada video dari kamera statis. Proses deteksi objek bergerak dengan metode tersebut didasarkan pada perbedaan antara latar belakang referensi dengan frame [2], [10], [11]. Namun proses deteksi hanya mempertimbangkan gerak kendaraan dan mengabaikan fitur kendaraan lainnya. Metode ini sensitif terhadap derau dan dapat mencapai tingkat kesalahan deteksi yang tinggi. kelemahan lainnya adalah jika munculnya bayangan dan pergerakan kecil dari lingkungan akibat perubahan intensitas cahaya akan mengakibatkan proses segmentasi tidak sempurna [12].

Penggunaan beberapa metode deteksi dan perhitungan kecepatan kendaraan yang sepenuhnya masih belum sempurna tersebut, menjadi alasan perlunya metode alternatif yang lebih baik dalam hal performa dan biaya. Penelitian ini menangani masalah pengawasan lalu lintas di siang hari, dan tujuannya untuk mengembangkan beberapa aspek yang telah dilakukan oleh para peneliti sebelumnya, baik itu metode deteksi dan juga perhitungan kecepatan kendaraan. Hasil deteksi kendaraan yang dilakukan akan digunakan sebagai parameter dalam perhitungan kecepatan. Hasil kecepatan akan ditampilkan pada perangkat indikator kecepatan. Kendaraan yang dideteksi adalah kendaraan roda empat (mobil, pikap, minibus, sedan, dll). Metode haar cascade classifier diterapkan dalam penelitian ini, yang merupakan hasil modifikasi dari sistem deteksi wajah yang disusulkan oleh Viola dan Jones, dengan prinsip deteksi objek berdasarkan nilai sederhana dari fitur tetapi bukan nilai piksel dari citra objek [13]. Metode ini sangat efektif dalam mendeteksi objek, yang merupakan gabungan beberapa konsep yaitu haar features, integral image, adaboost learning, dan cascade classifier [14][15]. 
Penelitian ini merupakan pengembangan penelitian sebelumnya, yaitu pengembangan dalam konsep deteksi dan estimasi kecepatan kendaraan. Estimasi kecepatan pada penelitian sebelumnya dilakukan dengan membagi area deteksi atau Region of Interest (ROI) menjadi dua area, yaitu area deteksi kendaraan saat awal masuk ROI dan saat keluar ROI, dan keduanya memiliki area yang cukup luas, sehingga akan mempengaruhi hasil deteksi kecepatan [16]. Permasalah tersebut perlu untuk dilakukan pengembangan yaitu dengan membuat ROI tunggal umtuk mempersempit area deteksi.

\section{METODE PENELITIAN}

Proses utama penelitian ini yaitu dimulai dari proses deteksi kendaraan menggunakan metode haar cascade classifier pada jalan raya. Proses awal dimulai dari memasukkan citra dalam bentuk video, yang diambil menggunakan kamera. Pemrosesan awal pada citra dilakukan dengan merubahan citra asli yaitu Red Green Blue (RGB) menjadi citra grayscale, dengan tujuan untuk menyederhanakan model citra. Selanjutnya akan ditentukan posisi ROI untuk membatasi area deteksi kendaraan sehingga deteksi lebih fokus dan akurat. Selanjutnya metode haar cascade classifier diterapkan dalam proses deteksi kendaraan. Metode ini memerlukan proses pelatihan classifier dari beberapa sampel citra dari objek, yang terdiri dari citra positif (kendaraan) dan citra negatif (latar belakang). Classifier yang dihasilkan dari proses pelatihan ini digunakan untuk proses deteksi objek.

Proses perhitungan kecepatan akan dilakukan untuk mengetahui estimasi waktu yang didapatkan dan hasilnya akan ditampilkan pada rambu kecepatan radar. Dalam Peraturan Pemerintah Republik Indonesia No. 79 Tahun 2013 Tentang Jaringan Lalu Lintas dan Angkutan Jalan, telah menetapkan batas kecepatan paling tinggi yang diterapkan pada jalan di kawasan permukiman yaitu $30 \mathrm{~km} / \mathrm{jam}$, sehingga kecepatan tersebut menjadi ambang batas dalam memberikan informasi lebih pada rambu kecepatan radar. Jika kecepatan $>30 \mathrm{~km} / \mathrm{jam}$, maka ditampilkan informasi tambahan "SLOW DOWN". Sebaliknya saat kecepatan $\leq 30 \mathrm{~km} / \mathrm{jam}$, ditampikan "THANK YOU”.

Tahapan lebih jelas dari penelitian akan dijelaskan sebagai berikut:

\subsection{Akuisisi Citra (Video)}

Proses awal penelitian ini adalah melakukan akuisi citra atau pengambilan video menggunakan kamera dan hasil video yang didapatkan akan dilakukan proses memasukan citra video kedalam program. Citra yang digunakan adalah video jalan raya dalam satu jalur dan arah, yang diambil menggunakan kamera dengan posisi dari samping jalan dan menghadap kebawah, seperti pada Gambar 1.

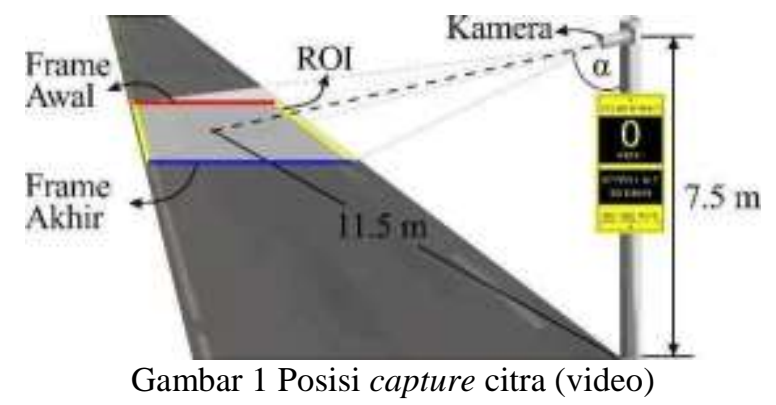

Penentuan posisi kamera dilakukan, dengan dimiringkan dan lurus dengan ROI, dan sudut kemiringan kamera ditentukan dengan menggunakan fungsi menghitung invers tangen (arctan), yaitu sebuah fungsi trigonometri, yang ditunjukkan pada persamaan (1).

dimana,

$$
\alpha=\tan ^{-1}(L / H) \alpha=\tan ^{-1}(L / H)(1)
$$


$\mathrm{L}=$ jarak tiang kamera dengan titik tengah $\mathrm{ROI}$

$\mathrm{H}=$ tinggi tiang penempatan kamera

Sehingga didapatkan nilai sudut kemiringan kamera $(\alpha)$ yaitu sebesar $56.89^{\circ}$.

Video yang masukkan ke dalam program akan dirubah resolusinya menjadi 320x240 piksel, dengan tujuan proses sistem lebih proporsional dan proses komputasi dapat berjalan lebih cepat.

Batasan masalah diberikan, dimana penelitian ini diperuntukkan pada jalan satu arah dan jalur, dengan tujuan mendeteksi dan mengetahui estimasi kecepatan kendaraan yang melintasi ROI dan hasilnya ditampilkan hasilnya pada sebuah layar rambu kecepatan radar. Pemberian ROI akan menentukan hasil deteksi, sehingga mengurangi resiko kesalahan deteksi dan proses yang dilakukan menjadi lebih fokus dan akurat. ROI ditentukan dengan memberikan titik-titik koordinat (x,y) dalam bentuk persegi panjang, seperti pada Gambar 2.

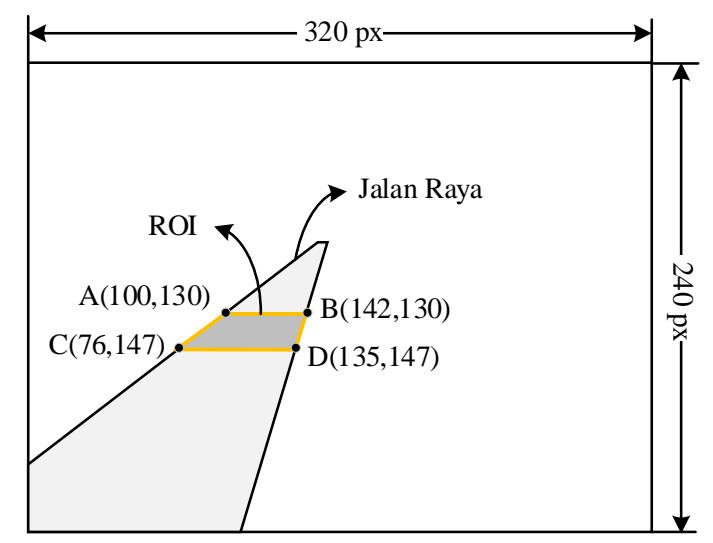

Gambar 2 Penentuan Region of Interest (ROI)

Untuk menentukan resolusi dari ROI (x,y), ditentukan terlebih dahulu koordinat $(\mathrm{x}, \mathrm{y})$, seperti pada Gambar 3.

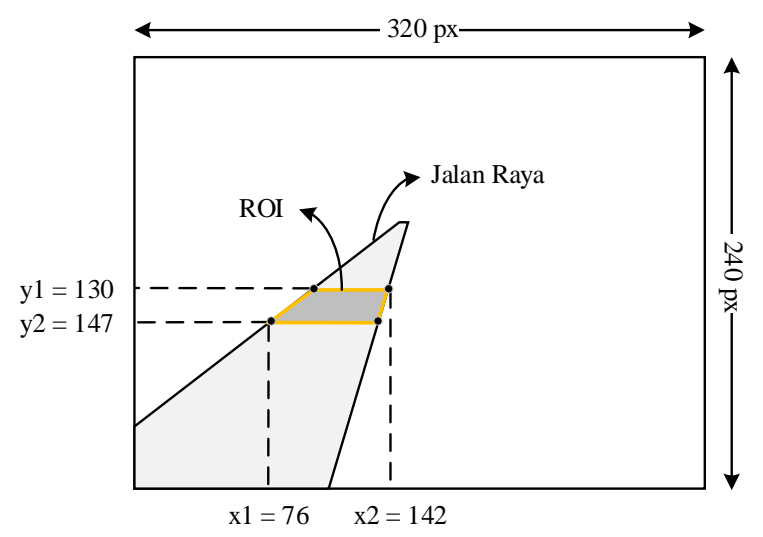

Gambar 3 Penentuan koordinat (x, y) ROI

Setelah penentuan koordinat (x,y) ROI, resolusi ditentukan dengan persamaan (2).

$$
\operatorname{ROI}(\mathrm{x}, \mathrm{y})=((\mathrm{x} 2-\mathrm{x} 1),(y 2-y 1)) \mathrm{ROI}(\mathrm{x}, \mathrm{y})=((\mathrm{x} 2-\mathrm{x} 1),(y 2-y 1))
$$

Sehingga didapatkan resolusi dari ROI yaitu 66x17 piksel.

\subsection{Pemrosesan Awal (Preprocessing)}

Citra video selanjutnya akan dikonversi dari warna asal RGB menjadi grayscale menggunakan fungsi cv2.cvtcolor yang telah disediakan pada OpenCV library, dan dilanjutkan 
pembacaan video secara frame by frame. Pada proses pemrosesan awal ini akan menghasilkan hasil berupa Region of Interest subcitra grayscale, yang merupakan hasil dari konversi grayscale pada daerah ROI.

\subsection{Deteksi Kendaraan}

Pada proses deteksi kendaraan menggunakan haar cascade classifier, terdapat beberapa proses yang dilakukan sebelum akhirnya didapatkan kendaraan yang terdeteksi pada sebuah citra, yaitu sebagai berikut:

\section{Pemilihan Fitur}

a. Haar-like Features

Citra yang sudah dirubah menjadi citra grayscale, selanjutnya dilakukan pememilihan fitur haar yang disebut juga dengan haar-like feature. Proses ini dilakukan dengan cara mengkotakkotakkan setiap daerah pada citra, mulai dari bagian kiri atas sampai kanan bawah, dengan tujuan untuk mencari apakah ada fitur kendaraan pada area tersebut.

Setiap kotak-kotak fitur terdiri dari beberapa piksel dan akan dihitung selisih antara nilai piksel pada kotak putih dengan kotak hitam. Apabila nilai selisih antara daerah putih dengan daerah hitam di atas nilai ambang (threshold), maka daerah tersebut dinyatakan memiliki fitur.

Pada citra kendaraan yang akan dideteksi, kondisinya menghadap ke depan dan untuk mempermudah dan mempercepat proses perhitungan nilai haar pada sebuah citra, haar cascade classifier menggunakan sebuah perhitungan yang disebut dengan integral image.

\section{b. Integral Image}

Integral image merupakan reperesentasi citra baru yang digunakan dalam menentukan keberadaan fitur haar pada sebuah citra secara efisien. Integral image membantu proses perhitungan hanya dengan satu kali pindai dan dengan waktu yang cepat dan akurat.

Nilai piksel yang dihitung merupakan nilai piksel dari sebuah citra masukan yang dilalui oleh fitur haar pada saat pencarian fitur kendaraan. Pada setiap jenis fitur yang digunakan pada setiap kotak terdiri dari beberapa piksel, seperti pada Gambar 4.

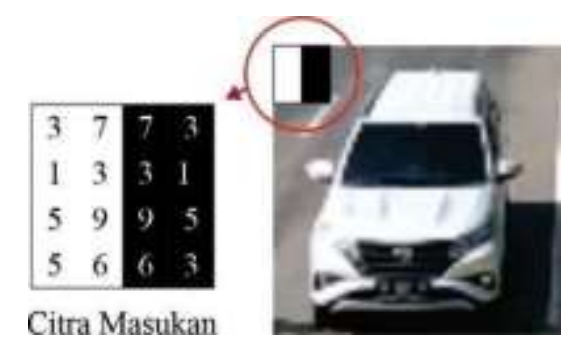

Gambar 4 Nilai piksel pada sebuah fitur

2. Klasifikasi Bertingkat

a. Adaptive Boosting (Adaboost)

Adaptive boosting merupakan teknik yang digunakan untuk mengkombinasikan banyak classifier lemah untuk membentuk suatu gabungan classifier yang lebih baik. Proses dari adaptive boosting akan menghasilkan sebuah classifier yang kuat dari classifier dasar. Satuan dari classifier dasar tersebut disebut dengan weak learner. Setelah sebelumnya dilakukan pemilihan fitur haar, pada proses selanjutnya dalam deteksi yaitu menggunakan algoritma adaboost, dimana fitur pada sebuah citra akan dideteksi kembali. Tujuannya untuk mengetahui apakah ada fitur kendaraan pada daerah dengan klasifikasi fitur yang lemah. Pada classifier lemah akan dilakukan perhitungan dan dibandingan dengan classifier lainnya secara acak. Selanjutnya dilakukan kombinasi atau penggabungan pada classifier lemah untuk membentuk suatu kombinasi yang linier.

\section{b. Cascade classifier}


Cascade classifier melakukan proses dari banyak fitur-fitur untuk mengorganisir dengan bentuk klasifikasi bertingkat. Terdapat tiga buah klasifikasi untuk menentukan apakah terdapat fitur kendaraan pada fitur yang sudah dipilih.

Pada klasifikasi penyaringan pertama, tiap sub-citra akan diklasifikasi menggunakan satu fitur. Jika hasil nilai fitur dari filter tidak memenuhi kriteria yang diinginkan, hasil tersebut akan ditolak.

Setelah itu, algoritma bergerak ke sub window selanjutnya dan menghitung nilai fitur kembali. Jika hasil yang didapatkan sesuai dengan threshold yang diinginkan, maka penyaringan dilanjutkan ke tahap selanjutnya hingga jumlah sub window yang lolos klasifikasi akan berkurang, mendekati citra yang dideteksi. Pada Gambar 5 menunjukkan proses rangkaian penyaringan yang dilalui oleh setiap classifier.

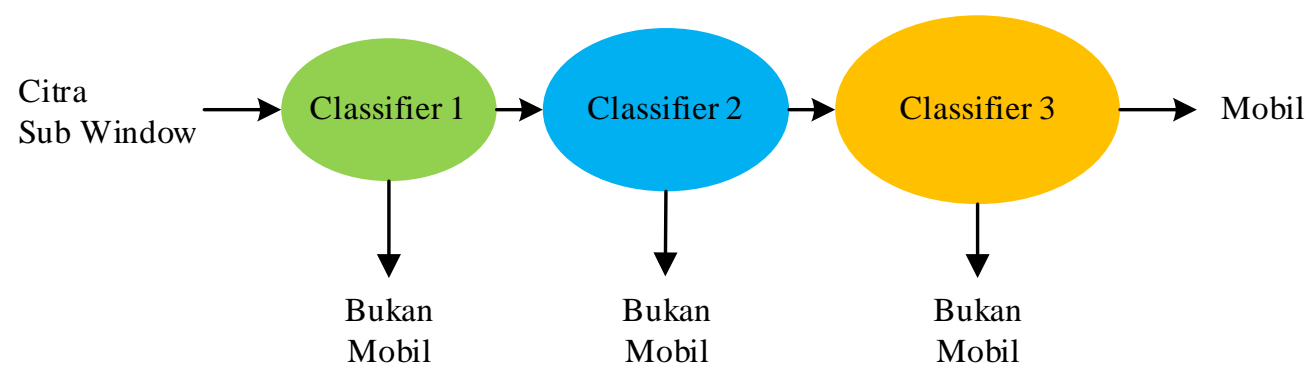

Gambar 5 Alur cascade classifier

Setelah proses pemilihan fitur dan klasifikasi bertingkat, akan didapatkan sebuah hasil pendeteksian yang bisa berupa mobil atau bukan. Pada saat proses klasifikasi bertingkat dilakukan maka, pada citra tersebut akan ditandai dengan sebuah kotak pembatas pada daerah kendaraan yang terdeteksi.

\subsection{Perhitungan Kecepatan}

Kendaraan yang terdeteksi selanjutnya diberikan bounding box dan centroid (titik tengah) sebagai titik referensi lokasi suatu objek dan membantu dalam mengetahui jarak mobil yang bergerak dalam frame secara berturut-turut, sehingga jumlah frame dari setiap pergerakan yang direkam akan diketahui, dan memungkinkan perhitungan kecepatan. Centroid yang diperoleh pada frame awal ROI dan frame akhir ROI digunakan untuk mencari nilai perpindahan jarak antar frame, dengan cara mencari selisih resultan antara koordinat frame akhir dengan koordinat frame awal, seperti pada Gambar 6.

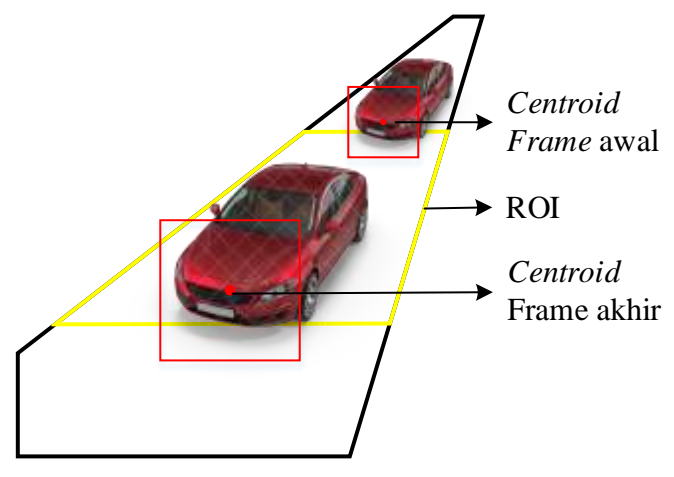

Gambar 6 Tampilan dari kamera pada daerah ROI

Kendaraan yang terdeteksi akan dihitung kecepatannya, dengan cara membagi panjang daerah dari ROI dengan waktu kendaraan. Dalam hal ini, ROI diukur panjangnya pada keadaan yang sesungguhnya. Pada Gambar 7 menunjukkan penempatan kamera pada ketinggian 7.5 meter dari permukaan. 


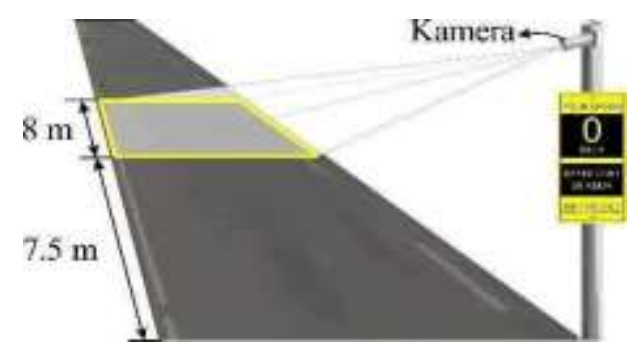

Gambar 7 Tampilan dari kamera pada daerah ROI

Untuk menghitung kecepatan kendaraan dilakukan dengan Persamaan (3). Parameter $V_{m} V_{m}$ menyatakan kecepatan kendaraan dalam meter/detik, s panjang daerah yang ditempuh (meter) dan $\mathrm{t}$ waktu tempuh kendaraan (detik). Untuk menghitung kecepatan dalam video, waktu tempuh kendaraan dapat dikembangkan menjadi Persamaan (4). Parameter $\mathrm{ft}$ menyatakan jumlah frame yang dihitung sejak kendaraan masuk sampai keluar ROI dan fps menyatakan kecepatan frame dari video (frame/detik). Subtitusi Persamaan (3) ke Persamaan (4) menghasilkan Persamaan (5) untuk menghitung kecepatan kendaraan pada video. Jumlah frame kendaraan ( $\mathrm{ft}$ ) dihitung dengan menggunakan Persamaan (6) dengan t menyatakan waktu kendaraan masuk sampai keluar ROI.

$$
\begin{gathered}
V_{m}=\frac{s}{t} V_{m}=\frac{s}{t} \quad \text { (3) } \\
t=\frac{f t}{f p s} t=\frac{f t}{f p s} \\
\text { kecepatan kendaraan }=\frac{s \cdot f p s}{f t} \text { kecepatan kendaraan }=\frac{s \cdot f p s}{f t} \\
f t=t x f p s f t=t x f p s \text { (6) }
\end{gathered}
$$

\subsection{Pengujian Sistem}

Pengujian sistem dilakukan untuk mengetahui tingkat keberhasilan sistem, baik dalam deteksi dan perhitungan kecepatan kendaraan. Selain itu, efektivitas pengujian diukur dalam 2 (dua) aspek. Pertama pada tingkat akurasi deteksi kendaraan, dan kedua adalah Mean Square Error (MSE) atau tingkat kesalahan rata-rata dari perhitungan kecepatan kendaraan.

Perbandingan objek kendaraan yang terdeteksi secara benar, dengan kesulurahan objek dalam video, digunakan untuk mengetahui tingkat akurasi hasil deteksi kendaraan dengan menggunakan persamaan (7).

$$
\text { Akurasi }=\frac{j \text { jumlah data benar }}{\text { keseluruhan data }} \times 100 \% \text { Akurasi }=\frac{j \text { jumlah data benar }}{\text { keseluruhan data }} \times 100 \%
$$

Proses selanjutnya mengukur tingkat keakuratan performa dari sistem menggunakan metode Mean Square Error (MSE). MSE digunakan untuk mengetahui perbedaan antara estimator dengan hasil estimasi, yang hasilnya berupa angka positif. Nilai yang mendekati nol maka kinerja estimator tersebut semakin baik. Untuk menghitung nilai MSE, digunakan persamaan (8). Parameter $\mathrm{N}$ menyatakan jumlah sampel, $y_{t} y_{t}$ menyatakan nilai aktual indeks dan $\hat{y_{t}} \hat{y_{t}}$ menyatakan prediksi indeks.

$$
\text { MSE }=\frac{1}{N} \sum_{i=h}^{W}\left(y_{t}-y_{t}^{\infty}\right)^{2} M S E=\frac{1}{N} \sum_{i=h}^{W}\left(y_{t}-y_{t}^{\infty}\right)^{2}
$$

\section{HASIL DAN PEMBAHASAN}


Pengujian sistem dilakukan dengan memperhatikan pesifikasi device yang digunakan diantaranya laptop dengan prosesor i3-4030U 1.90GHz, RAM 6 GB, dan sistem operasi Windows 10. Selain itu, 5 video pada jalan raya digunakan sebagai data uji, dengan tampilan seperti pada Gambar 8, dan sampel citra yang digunakan tediri dari 600 citra positif (objek mobil) dan 1000 citra negatif (background) yang di latih dengan bantuan library OpenCV. Sampel positif diperoleh dengan memotong dan mengubah ukuran citra secara manual menjadi 30 x 30 piksel, seperti pada Gambar 9 .

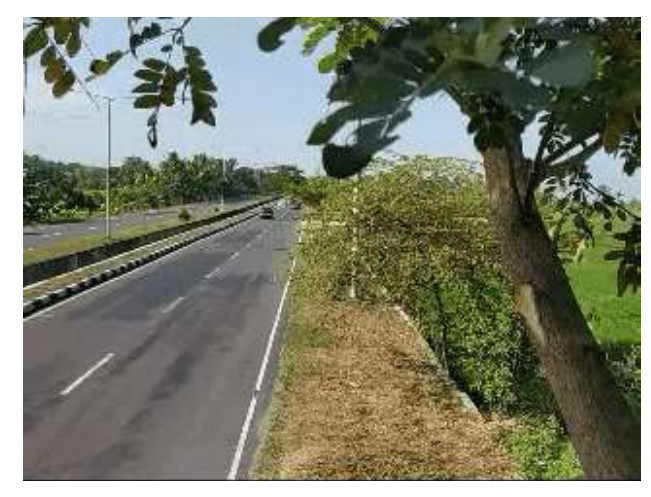

Gambar 8 Tampilan lalu lintas pada jalan raya

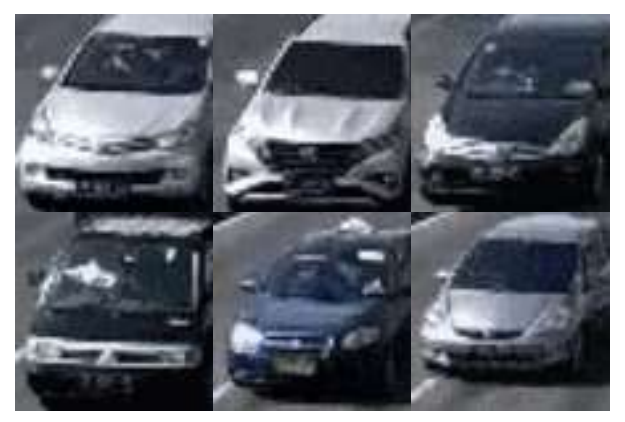

Gambar 9 Citra sampel positif

Sistem dirancang secara simulasi, namun tetap dapat diterapkan secara real time dengan embedded system menggunakan raspberry pi yang terintegrasi dengan kamera sebagai sensor visual untuk mengambil citra dan display sebagai radar speed sign. Sistem akan memproses sumber video dengan tahap-tahap yang telah ditentukan. Dari video tersebut, akan diberikan batasan area deteksi (ROI) seperti pada Gambar 10.

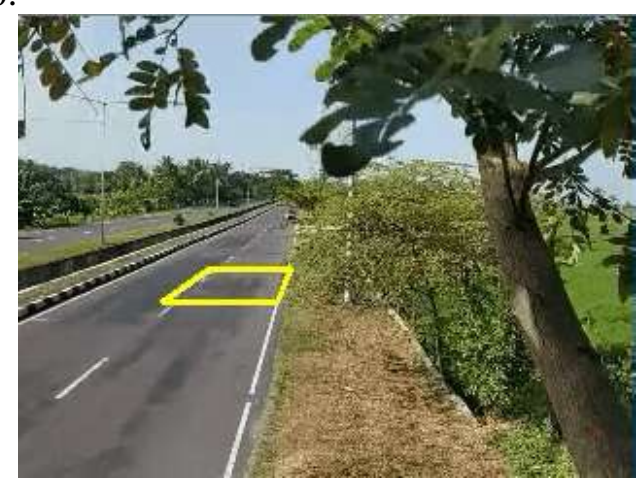

Gambar 10 Batasan area deteksi (ROI) 
Dalam proses deteksi, jika terdapat objek kendaraan (mobil) terdeteksi pada kedua ROI, maka akan ditandai dengan bounding box (kotak merah), seperti yang ditunjukkan pada Gambar 11.

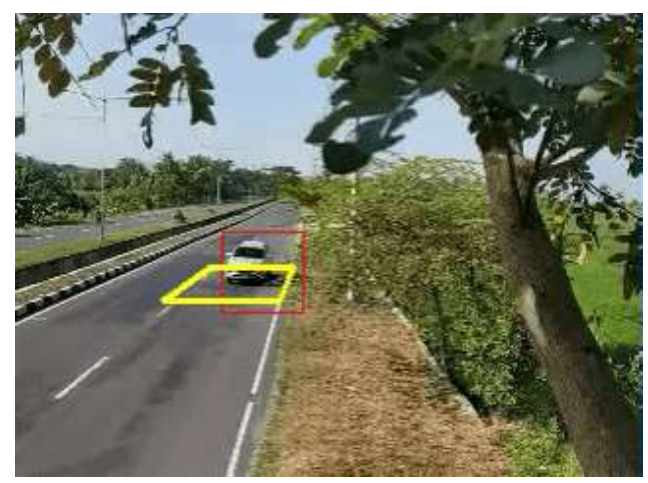

Gambar 11 Tampilan hasil deteksi mobil pada ROI

Hasil deteksi yang telah dilakukan menentukan hasil perhitungan kecepatan. Sehingga hanya kendaraan yang terdeteksi dalam ROI yang akan dihitung kecepatannya. Dengan menggunakan persamaan yang telah ditentukan, parameter pertama yang diperlukan dalam perhitungan adalah jarak dari ROI yang diukur panjangnya pada keadaan sesungguhnya. Parameter kedua adalah jumlah frame yang dihitung sejak mobil terdeteksi pada frame awal ROI sampai dengan saat kendaraan terdeteksi pada frame akhir ROI. Dengan kedua parameter tersebut, kecepatan kendaraan akan diketahui.

Tampilan radar speed sign pada setiap keadaan berbeda. Pada Gambar 12 menunjukkan 3 tampilan radar speed sign disetiap keadaan, dimana (a) saat belum terdapat kendaraan yang melintasi ROI $(0 \mathrm{~km} / \mathrm{jam})$, dengan informasi tambahan "SPEED LIMIT $30 \mathrm{KM} / \mathrm{H}$ ", untuk memberikan informasi bahwa batas kecepatan yang diberikan adalah $30 \mathrm{~km} / \mathrm{jam}$, (b) saat kendaraan melintas dengan kecepatan $\leq 30 \mathrm{~km} / \mathrm{jam}$ atau kecepatan yang masih diizinkan, dengan informasi tambahan "THANK YOU", dan (c) saat kendaraan melintas dengan kecepatan $>30 \mathrm{~km} / \mathrm{jam}$, dengan informasi tambahan "SLOW DOWN" untuk mengingatkan kepada pengemudi untuk mengurangi kecepatan kendaraan.

Pengujian penelitian ini hanya dilakukan secara simulasi, sehingga tampilan radar speed sign diberikan atau ditampilkan pada bagian video output, untuk mengetahui hasil deteksi dan estimasi kecepatan kendaraan. Gambar 13 (a) menunjukkan hasil estimasi kecepatan kendaraan pada kondisi $>30 \mathrm{~km} / \mathrm{jam}$, dan (b) kondisi kecepatan mobil $\leq 30 \mathrm{~km} / \mathrm{jam}$. 


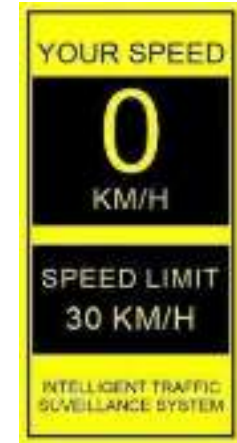

(a)

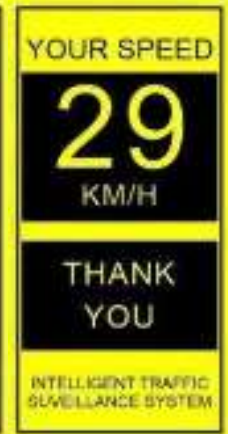

(b)

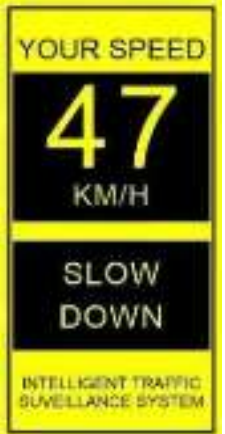

(c)

Gambar 12 Tampilan Radar Speed Sign, (a) tidak ada kendaraan melintas, (b) kecepatan $\leq$ $30 \mathrm{~km} / \mathrm{jam}$, dan (c) kecepatan $>30 \mathrm{~km} / \mathrm{jam}$
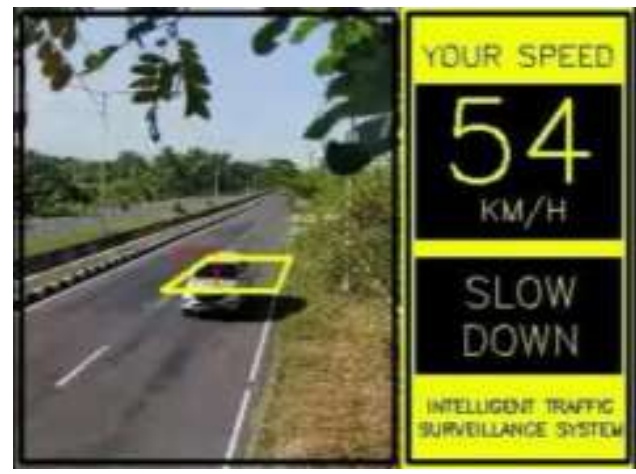

(a)
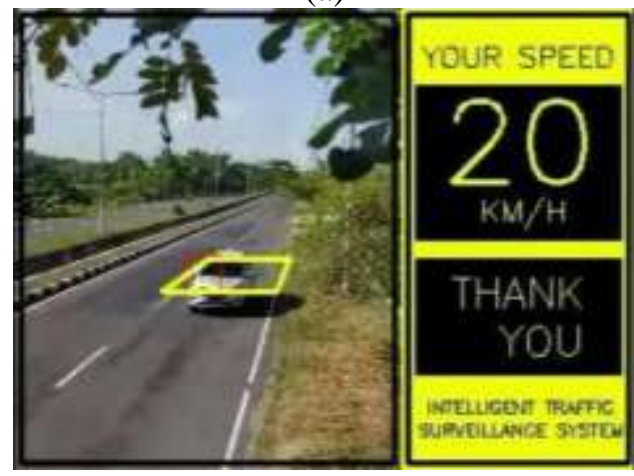

(b)

Gambar 13 Tampilan hasil estimasi kecepatan kendaraan, (a) $>30 \mathrm{~km} / \mathrm{jam}$, (b) $\leq 30$ $\mathrm{km} / \mathrm{jam}$

Pada tahap pengujian menggunakan 5 video, sebagai pengujian data realistik video pengawas lalu lintas, didapatkan hasil pada Tabel 1.

Tabel 1 Deskripsi pengujian video

\begin{tabular}{|c|c|c|c|}
\hline No. & Video Pengujian & Waktu & Jumlah Mobil \\
\hline 1 & Vid1.mp4 & Siang & 51 \\
\hline 2 & Vid2.mp4 & Siang & 40 \\
\hline 3 & Vid3.mp4 & Sore & 45 \\
\hline 4 & Vid4.mp4 & Sore & 60 \\
\hline 5 & Vid5.mp4 & Sore & 44 \\
\hline
\end{tabular}

Pengujian pengukuran tingkat deteksi classifier dilakukan untuk mendapatkan nilai recall dan presisi menggunakan nilai faktor skala yang berbeda, sehingga dapat menentukan nilai yang dapat memberikan kinerja terbaik bagi classifier. Pada Tabel 2, ditunjukkan hasil pengujian data dari 
classifier dengan menggunakan 3 sampel video pengujian dan 3 nilai faktor skala yang berbeda. Setiap nilai faktor skala menghasilkan tingkat deteksi yang berbeda. Untuk mendapatkan tingkat deteksi yang tinggi, nilai faktor skala harus ditentukan untuk memberikan kinerja terbaik untuk classifier. Berdasarkan Tabel 2, nilai faktor skala 1.3 memberikan kinerja terbaik untuk classifier dan akan digunakan dalam seksi pengujian deteksi kendaraan. Selain itu, nilai rata-rata recall didapatkan adalah 1 , dan nilai rata-rata presisi adalah 0,969 .

Tahap selanjutnya yaitu melakukan pengujian deteksi kendaraan dari 5 video pengujian. Hasil yang didapatkan ditunjukkan dalam Tabel 3, dimana didapatkan nilai rata-rata recall adalah 0.988, dan nilai rata-rata presisi adalah 0,970 .

Setelah objek mobil terdeteksi, diperlukan pengujian lebih lanjut untuk membuktikan keakuratan perhitungan kecepatan yang dihasilkan pada sistem dengan perhitungan kecepatan dari video. Namun sebelum hal tersebut dilakukan, diperlukan verifikasi hasil dari kecepatan secara real time dengan kecepatan pada video. Hal tersebut dilakukan dengan cara melihat kecepatan yang ditampilkan pada speedometer pada saat mobil melintasi ROI. Kecepatan yang dihasilkan menjadi sumber utama kecepatan pada video dan dilakukan perbandingan kecepatan pada sistem. Pengujian dilakukan dengan menggunakan lima sampel mobil yang dihitung akurasi pendeteksiannya pada pembahasan sebelumnya dan hasil perhitungan kecepatan tersebut ditunjukkan pada Tabel 4.

Tabel 2 Deteksi tingkat pengujian

\begin{tabular}{|c|c|c|c|c|c|c|c|}
\hline $\begin{array}{c}\text { Video } \\
\text { Pengujian }\end{array}$ & $\begin{array}{c}\text { Skala } \\
\text { Faktor }\end{array}$ & $\begin{array}{c}\text { Jumlah Mobil } \\
\text { Sebenarnya }\end{array}$ & TP & FP & FN & $\begin{array}{c}\text { Recall } \\
\frac{T P}{T P+F N}\end{array}$ & $\begin{array}{c}\text { Presisi } \\
\frac{T P}{T P}\end{array}$ \\
\hline Vid1.mp4 & 1.3 & 50 & 49 & 1 & 0 & 1.000 & 0.980 \\
\hline Vid2.mp4 & 1.3 & 40 & 38 & 2 & 0 & 1.000 & 0.950 \\
\hline Vid3.mp4 & 1.3 & 45 & 44 & 1 & 0 & 1.000 & 0.978 \\
\hline \multicolumn{7}{|l|}{ Rata-rata (Faktor Skala 1.3) } \\
\hline Vid1.mp4 & 1.5 & 50 & 49 & 1 & 0 & 1.000 & 0.980 \\
\hline Vid2.mp4 & 1.5 & 40 & 35 & 5 & 0 & 1.000 & 0.875 \\
\hline Vid3.mp4 & 1.5 & 45 & 42 & 3 & 0 & 1.000 & 0.933 \\
\hline \multicolumn{7}{|l|}{ Rata-rata (Faktor Skala 1.5) } \\
\hline Vid1.mp4 & 1.7 & 50 & 49 & 1 & 0 & 1.000 & 0.980 \\
\hline Vid2.mp4 & 1.7 & 40 & 36 & 4 & 2 & 0.947 & 0.900 \\
\hline Vid3.mp4 & 1.7 & 45 & 5 & 0 & 1.000 & 0.889 \\
\hline
\end{tabular}

Tabel 3 Hasil pendeteksian kendaraan

\begin{tabular}{|c|c|c|c|c|c|c|c|}
\hline No & $\begin{array}{c}\text { Video } \\
\text { Pengujian }\end{array}$ & $\begin{array}{c}\text { Jumlah Mobil } \\
\text { Sebenarnya }\end{array}$ & $\mathbf{T P}$ & FP & FN & Recall & Presisi \\
\hline 1 & Vid1.mp4 & 50 & 49 & 1 & 0 & 1.000 & 0.980 \\
\hline 2 & Vid2.mp4 & 40 & 38 & 2 & 0 & 1.000 & 0.950 \\
\hline 3 & Vid3.mp4 & 45 & 44 & 1 & 0 & 1.000 & 0.978 \\
\hline 4 & Vid4.mp4 & 60 & 58 & 2 & 1 & 0.983 & 0.967 \\
\hline 5 & Vid5.mp4 & 44 & 43 & 1 & 2 & 0.956 & 0.977 \\
\hline \multicolumn{6}{|c|}{ Rata-rata } & 0.988 & 0.970 \\
\hline
\end{tabular}

Tabel 4 Hasil perhitungan kecepatan

\begin{tabular}{|c|c|c|c|c|c|c|}
\hline Mobil & $\begin{array}{c}\text { Kec. Program } \\
\left(\mathbf{F}_{\mathrm{t}}\right)\end{array}$ & $\begin{array}{c}\text { Kec. Video } \\
\left(\mathbf{A}_{\mathbf{t}}\right)\end{array}$ & $\begin{array}{c}\text { Error } \\
\left(\mathbf{A}_{t}-F_{t}\right)\end{array}$ & $\begin{array}{l}\text { Square of Error } \\
(\mathrm{At}-\mathrm{Ft})^{2}\end{array}$ & Total & MSE \\
\hline 1 & 21 & 20 & 1 & 1 & \multirow{5}{*}{3} & \multirow{5}{*}{0.6} \\
\hline 2 & 30 & 30 & 0 & 0 & & \\
\hline 3 & 40 & 40 & 0 & 0 & & \\
\hline 4 & 51 & 50 & 1 & 1 & & \\
\hline 5 & 59 & 60 & 1 & 1 & & \\
\hline
\end{tabular}


Berdasarkan hasil pengujian perhitungan kecepatan, nilai rata-rata MSE yang didapatkan yaitu 0,6. Hasil tersebut masih jauh dari kata sempurna dalam pehitungan kecepatan, dimana nilai yang sempurna yaitu nilai error yang sangat kecil yaitu mendekati 0 (nol). Hasil yang belum sempurna, disebabkan karena beberapa faktor. Masalah umum yang terjadi yaitu terdapat proses komputasi yang berat dan mengakibatkan sistem berjalan lambat. Dimungkinkan sistem akan berjalan lebih baik jika diterapkan pada device dengan spesifikasi yang lebih tinggi, sehingga dapat menghasilkan perhitungan kecepatan yang sesuai dengan video secara real time.

Pemanfaat kamera dalam deteksi kecepatan kendaraan, menunjukkan hasil yang lebih baik sebagai sensor deteksi dibandingkan menggunakan pistol radar [1], [2], dan sensor elektronik [3], [4]. Selain itu, penggunaan kamera dapat membantu membangun sistem yang aman dan murah dalam sistem pengawasan lalu lintas [5], dengan didukung oleh perkembangan computer vision, menjadikan penggunaan kamera merupakan cara yang efisien dalam mengumpulkan dan menganalisis data lalu lintas [6]. Pengaplikasian indikator rambu kecepatan radar dalam proses penegakan, memiliki manfaat yang lebih efektif, baik dalam hal biaya dan kegunaannya dalam menampilkan kecepatan kendaraan sehingga dapat membantu mengurangi kecelakaan pada pengemudi dan mengurangi tugas dari polisi lalu lintas [7]-[9].

Dalam proses deteksi kendaraan menggunakan metode haar cascade classifier, terdapat berbagai kelebihan yang dimiliki jika dibandingkan dengan metode-metode yang diterapkan dalam penelitian sebelumnya [10]-[12]. Metode ini sangat efektif dan memberikan hasil yang lebih baik dalam penerapannya untuk klasifikasi dan deteksi kendaraan dengan nilai rata-rata recall 0.988 dan presisi 0.97 dari 5 video pengujian yang digunakan, dan sistem bekerja secara baik yang didukung oleh intensitas cahaya yang baik, dengan pengambilan video pada waktu siang dan sore hari [13]-[15]. Penggunaan metode ini dalam deteksi kendaraan cukup memberikan hasil yang akurat dan menjanjikan [16]. Namun adanya hasil yang belum sepenuhnya sempurna menunjukkan bahwa metode ini tidak bekerja dengan baik dengan berbagai orientasi kendaraan pada video lalu lintas, yang memberikan adanya kesalahan deteksi (objek lain terdeteksi sebagai mobil). Pemberian ROI dan penentuan nilai faktor skala yang tepat dalam proses klasifikasi menjadi solusi untuk memperkecil kesalahan deteksi, mendapatkan hasil yang akurat dan kinerja yang baik.

\section{KESIMPULAN DAN SARAN}

Penelitian ini merancang sistem klasifikasi, deteksi dan perhitungan kecepatan dari berbagai jenis kendaraan tertentu. Haar casacade classifier yang dikemukakan oleh Paul Viola dan Michael Jones digunakan untuk mendeteksi kendaraan yang melintas di jalan raya dengan menggunakan input video lalu lintas. Tingkat deteksi sistem ini dipengaruhi oleh nilai faktor skala, dimana pemberian nilai yang berbeda dapat memberikan tingkat deteksi yang bervariasi. Untuk mendapatkan tingkat deteksi yang tinggi, harus ditentukan nilai faktor skala yang memberikan kinerja terbaik untuk classifier. Hasil estimasi perhitungan kecepatan yang menerapkan batas area deteksi (ROI) menunjukkan kinerja yang baik. Penelitian kedepannya, diperlukan sebuah sistem yang dapat dilakukan pada malam hari atau dengan kondisi instensitas cahaya rendah. Selain itu, menyediakan sistem deteksi kendaraan yang akurat dan kuat akan tetap menjadi tugas yang menantang di bidang sistem pengawasan transportasi cerdas. Penelitian selanjutnya akan dilakukan lebih lanjut, untuk membandingkan metode background substraction dan haar cascade classifier atau menggabungkan keduanya untuk mendeteksi jenis kendaraan yang lebih spesifik.

\section{DAFTAR PUSTAKA}

[1] S. Jeng, W. Chieng, and H. Lu, "Estimating Speed Using a Side-Looking Single-Radar Vehicle Detector," IEEE Trans. Intell. Transp. Syst., vol. 15, no. 2, pp. 607-614, 2014.

[2] P. K. Thadagoppula and V. Upadhyaya, "Speed detection using image processing," Int. Conf. Comput. Control. Informatics its Appl., pp. 11-16, 2016, doi: 10.1109/IC3INA.2016.7863015. 
[3] C. Y. Ho, H. Y. Lin, and L. T. Wu, "Intelligent speed bump system with dynamic license plate recognition," IEEE Int. Conf. Ind. Technol., pp. 1669-1674, 2016, doi: 10.1109/ICIT.2016.7475013.

[4] L. E. Y. Mimbela, "A Summary of Vehicle Detection and Surveillance Technologies used in Intelligent Transportation Systems," Fed. Highw. Adm. Intell. Transp. Syst. Progr. Off., 2007.

[5] J. Damsere-Derry, R. Lumor, S. Bawa, and D. Tikoli, "Effects of Traffic Calming Measures on Mobility, Road Safety and Pavement Conditions on Abuakwa-Bibiani Highway," Front. Sustain. Cities, vol. 2, no. June, pp. 1-9, 2020, doi: $10.3389 /$ frsc. 2020.00026 .

[6] N. Buch, S. A. Velastin, and J. Orwell, "A review of computer vision techniques for the analysis of urban traffic," IEEE Trans. Intell. Transp. Syst., vol. 12, no. 3, pp. 920-939, 2011, doi: 10.1109/TITS.2011.2119372.

[7] Carmanah Technologies Corp., "Radar Speed Signs Top Traffic Calming List," Traffic Calming \& Vision Zero, 2019. https://carmanah.com/articles/radar-speed-signs-top-trafficcalming-list/ (accessed Jan. 04, 2021).

[8] M. Li, A. Faghri, and R. Fan, "Determining Ideal Locations for Radar Speed Signs for Maximum Effectiveness: A Review of the Literature," Dep. Civ. Environ. Eng. Univ. Delaware, 2017.

[9] L. Radarsign, "How Effective are Radar Speed Signs? | radarsign.com." https://www.radarsign.com/how-effective-are-radar-speed-signs/ (accessed Jan. 06, 2021).

[10] A. Varghese and G. Sreelekha, "Background Subtraction for Vehicle Detection," Glob. Conf. Commun. Technol., pp. 380-382, 2015, doi: 10.1109/GCCT.2015.7342688.

[11] R. A. Yuha and M. Harahap, "Deteksi Gerakan pada Kamera CCTV dengan Algoritma Frame Difference dan Frame Substraction," Semin. Nas. Teknol. Inf. dan Komun., pp. 503$511,2019$.

[12] Q. Wu, W. Kang, and X. Zhuang, "Real-time vehicle detection with foreground-based cascade classifier," IET Image Process., vol. 10, no. 4, pp. 289-296, 2016, doi: 10.1049/iet-ipr.2015.0333.

[13] P. Viola and M. Jones, "Rapid object detection using a boosted cascade of simple features," IEEE Comput. Soc. Conf. Comput. Vis. Pattern Recognit., vol. 1, pp. 511-518, 2001, doi: 10.1109/CVPR.2001.990517.

[14] D. K. Ulfa and D. H. Widyantoro, "Pelaksanaan Haar Cascade Classifier untuk Deteksi Motorcycle," IEEE Int. Conf. Cybern. Comput. Intell., 2017.

[15] S. Choudhury, S. P. Chattopadhyay, and T. K. Hazra, "Vehicle Detection and Counting using Haar Feature- Based Classifier," 8th Annu. Ind. Autom. Electromechanical Eng. Conf., pp. 106-109, 2017.

[16] M. Zulfikri, E. Yudaningtyas, K. Kendaraan, H. Cascade, and J. Teknologi, "Sistem Penegakan Speed Bump Berdasarkan Kecepatan Kendaraan yang Diklasifikasikan Haar Cascade Classifier," J. Teknol. dan Sist. Inf., vol. 7, no. 1, pp. 12-18, 2019, doi: 10.14710/jtsiskom.7.1.2019.12-18.

[17] D. Jomaa, S. Yella, and M. Dougherty, "A Comparative Study between Vehicle Activated Signs and Speed Indicator Devices," Transp. Res. Procedia, vol. 22, no. 2016, pp. 115123, 2017, doi: 10.1016/j.trpro.2017.03.017.

[18] A. Ullah, S. Hussain, A. Wasim, and M. Jahanzaib, "Usage and impacts of speed humps on vehicles: A review," J. Adv. Rev. Sci. Res. J. homepage, vol. 28, no. 1, pp. 1-17, 2016, [Online]. Available: www.akademiabaru.com/arsr.html.

[19] A. Khan, D. M. S. Z. Sarker, and S. Rayamajhi, "Speed Estimation of Vehicle in Intelligent Traffic Surveillance System Using Video Image Processing," Int. J. Sci. Eng. Res., vol. 5, no. 12, pp. 1384-1390, 2014, doi: 10.14299/ijser.2014.12.003.

[20] H. J. Kim, "Vehicle detection and speed estimation for automated traffic surveillance systems at nighttime," Tech. Gaz., vol. 26, no. 1, pp. 87-94, 2019, doi: 10.17559/TV20170827091448. 
Techno.COM, Vol. 20, No.3, Agustus 2021: 456-468 